\title{
Metabolic control of type I (insulin dependent) diabetes after pancreas transplantation
}

\author{
GUIDO POZZA, EMANUELE BOSI, ANTONIO SECCHI, PIER MARCO PIATTI, \\ JEAN LOUIS TOURAINE, ALBERT GELET, ANTONIO E PONTIROLI, \\ JEAN MICHEL DUBERNARD, JULES TRAEGER
}

\begin{abstract}
A study was conducted of the circadian hormonal and metabolic patterns of 10 type I (insulin dependent) uraemic diabetic patients after pancreas and renal transplantation. A single 24 hour profile was obtained in each patient following as closely as possible his or her normal daily routine two to 15 months after transplantation. None of the patients were using insulin at the time of the study. Compared with a group of six normal subjects the transplant recipients had mildly raised blood glucose concentrations, hyperinsulinaemia between meals and at night, delayed postprandial insulin peaks, mild hyperketonaemia, and normal blood lactate and plasma glucagon concentrations.

The findings showed that successful pancreas transplantation results in disappearance of the need for insulin and return to normal or near normal of the metabolic abnormalities of diabetes. The minor differences observed in comparison with normal hormonal and metabolic homoeostasis were probably due to intrinsic (reduced islet mass, denervation, peripheral hormone delivery) and environmental (immunosuppression, relatively impaired renal function) factors.
\end{abstract}

\section{Introduction}

The correction of metabolic abnormalities in type I (insulin dependent) diabetes depends on appropriate insulin replacement, ideally by means of a pancreas transplant able to regulate insulin production. In man this has been attempted only by transplanting the whole pancreas or a segment of it, transplantation of isolated islets having proved unsuccessful for technical and immunological reasons. ${ }^{1-3}$ Reports show that successful pancreas transplants lead to the disappearance of insulin dependence and of the clinical signs and symptoms of diabetes (hyperglycaemia, glycosuria, ketosis, polyuria, polydipsia). ${ }^{4-7}$ We have found that the insulin response to acute secretory stimuli is restored after pancreas transplantation..$^{8-10}$ Nevertheless, the resulting hormonal and metabolic features have not been investigated.

Istituto Scientifico San Rafiaele, Cattedra di Clinica Medica, Universitá di Milano, Italy; and Hôpital Edouard Herriot, Clinique de Nephrologie et Maladies Metaboliques, and Service d'Urologie et Chirurgie de la Transplantation, INSERM U 80, Lyon, France GUIDO POZZA, MD, professor of medicine and director of clinica medica, ISR

EMANUELE BOSI, MD, physician, ISR

ANTONIO SECCHI, MD, physician, ISR

PIER MARCO PIATTI, MD, postgraduate fellow in diabetes

JEAN LOUIS TOURAINE, MD, associate professor of nephrology

ALBERT GELET, MD, senior registrar in urology

ANTONIO E PONTIROLI, MD, established investigator, ISR

JEAN MICHEL DUBERNARD, $M D$, professor of urology and transplant surgery

JULES TRAEGER, MD, professor of nephrology

Correspondence and requests for reprints to: Professor Guido Pozza, Istituto San Raffaele, via Olgettina 60, I-20132 Milano, Italy.
This study aimed at characterising the 24 hour endocrine and metabolic patterns of 10 recipients of successful pancreas transplants while following as closely as possible their usual daily routines.

\section{Patients and methods}

We studied 10 type I diabetic patients who were treated by simultaneous cadaveric donor pancreas and kidney transplantation. Table I summarises their clinical characteristics. All had been in end stage renal failure due to diabetic nephropathy and nine were receiving haemodialysis before transplantation; all had received laser photocoagulation for severe retinopathy, three of them being blind at the time of transplantation; and all had severe somatic and autonomic diabetic neuropathy. Residual $\beta$ cell function before transplantation was nil or minimal, the plasma $C$ peptide concentration being $<0.02$ $\mathrm{nmol} / 1(<0.06 \mathrm{ng} / \mathrm{ml})$ fasting or after a mixed meal. At the time of investigation all patients had normal fasting blood glucose values, were independent of insulin, and had satisfactory renal graft function (table I).

Transplantation-In each case the pancreas and renal grafts were transplanted simultaneously from the same cadaveric donor using a technique previously described. ${ }^{11}$ Briefly, pancreatic exocrine secretion was suppressed by injecting neoprene (a liquid rubber which hardens on contact with the pancreatic juice) into the ductal system. In nine cases the pancreatic graft was segmental (body and tail), and in one case the whole pancreas was transplanted. Pancreas grafts were placed in the right iliac fossa of the recipients and revascularised by anastomosis to the right iliac vessels; the renal grafts were placed in the opposite iliac fossa.

Immunological preparation and immunosuppression-In all cases donors and recipients were matched on the basis of $A B O$ compatibility and negative cross match. The number of HLA-A and $B$ antigen shared between donors and recipients were none in four cases, one in four cases, two in one case, and three in one case. All patients were prepared immunologically by blood transfusions of 3-10 units. At the time of investigation four patients were receiving cyclosporin, given as sole immunosuppressive treatment in two cases and with steroids in the other two; the remaining six patients were receiving azathioprine and steroids (table I). The doses of immunosuppressive drugs at the time of study were: cyclosporin $5-7 \mathrm{mg} / \mathrm{kg} /$ day; steroids $0 \cdot 2-0 \cdot 5$ $\mathrm{mg} / \mathrm{kg} /$ day; azathioprine $1 \cdot 5-2.5 \mathrm{mg} / \mathrm{kg} /$ day.

Study protocol-A single metabolic profile was obtained in all cases. In five patients (cases $2,3,5,7$, and 10) studies were carried out during their postoperative stay in hospital, while the remaining patients were readmitted to hospital one day before the study and remained in hospital throughout. The study lasted 24 hours, during which the patients followed their usual patterns of rest and physical and intellectual activities as closely as possible. Meals were taken as follows: breakfast at 0700 , snack at 1000 , lunch at 1300 , and dinner at 1830 , providing $20 \%, 10 \%, 40 \%$, and $30 \%$ of the daily energy intake, respectively $(0 \cdot 15 \mathrm{MJ}(35 \mathrm{kcal}) / \mathrm{kg}$ body weight/day; $45 \%$ carbohydrate, $35 \%$ fats, $20 \%$ protein). Patients were ambulant during the study, except for a five minute rest before each blood sampling. Twenty blood samples were obtained without haemostasis (using a 16 or 18 gauge catheter inserted into an antecubital vein and kept patent by an obturator) at $0700,0730,0800,0900,1000,1100,1200,1300,1330$ $1400,1500,1600,1700,1830,1900,2000,2100,2400,0300$, and 0500 . Blood glucose, serum free insulin, plasma glucagon, and blood lactate and $\beta$-hydroxybutyrate concentrations were measured in all samples (see below)

Controls-Six lean 22-27 year old healthy volunteers without a family history of diabetes mellitus and with normal fasting blood glucose concentrations and normal oral glucose tolerance were studied under 
TABLE I-Clinical characteristics of 10 patients with type $I$ diabetes and end stage renal failure given simultaneous pancreas $(P)$ and kidney $(K)$ transplants

\begin{tabular}{|c|c|c|c|c|c|c|c|c|c|c|}
\hline $\begin{array}{l}\text { Case } \\
\text { No }\end{array}$ & Sex & $\begin{array}{l}\text { Age } \\
\text { (years) }\end{array}$ & $\begin{array}{l}\text { Duration of } \\
\text { diabetes } \\
\text { (years) }\end{array}$ & $\begin{array}{l}\text { Type of } \\
\text { transplant }\end{array}$ & $\begin{array}{l}\text { Date of } \\
\text { operation }\end{array}$ & $\begin{array}{l}\text { Time between } \\
\text { transplantation } \\
\text { and investigation } \\
\text { (months) }\end{array}$ & $\begin{array}{l}\text { Immunosuppressive } \\
\text { treatment }\end{array}$ & $\underset{(\%)}{\mathbf{H b A}_{\mathbf{1}}}$ & $\begin{array}{l}\text { Plasma } \\
\text { creatinine } \\
(\mu \mathrm{mol} / \mathrm{l})\end{array}$ & State at 1 January 1985 \\
\hline $\begin{array}{r}1 \\
2 \\
3 \\
4 \\
5 \\
6 \\
7 \\
8 \\
9 \\
10\end{array}$ & $\begin{array}{l}M \\
M \\
M \\
F \\
M \\
M \\
F \\
M \\
M \\
F\end{array}$ & $\begin{array}{l}27 \\
28 \\
40 \\
27 \\
33 \\
36 \\
28 \\
38 \\
30 \\
35\end{array}$ & $\begin{array}{r}16 \\
13 \\
14 \\
25 \\
20 \\
22 \\
16 \\
26 \\
18 \\
5\end{array}$ & $\begin{array}{l}P+K \\
P+K \\
P+K \\
P+K \\
P+K \\
P+K \\
P+K \\
P+K \\
P+K \\
P+K\end{array}$ & $\begin{array}{l}\text { Nov ',81 } \\
\text { Mar '82 } \\
\text { Apr'82 } \\
\text { Mar '81 } \\
\text { Apr '83 } \\
\text { Jan '83 } \\
\text { May ', } 83 \\
\text { Apr '83 } \\
\text { Aug '83 } \\
\text { Sep '83 }\end{array}$ & $\begin{array}{r}3 \\
2 \\
2 \\
15 \\
2 \\
5 \\
2 \\
5 \\
4 \\
3\end{array}$ & $\begin{array}{l}\text { Cyclosporin A } \\
\text { Cyclosporin A + steroids } \\
\text { Cyclosporin A + steroids } \\
\text { Cyclosporin A } \\
\text { Azathioprine + steroids } \\
\text { Azathioprine + steroids } \\
\text { Azathioprine + steroids } \\
\text { Azathioprine + steroids } \\
\text { Azathioprine + steroids } \\
\text { Azathioprine + steroids }\end{array}$ & $\begin{array}{l}5 \cdot 76 \\
5 \cdot 63 \\
5.49 \\
8 \cdot 72 \\
6.54 \\
5.06 \\
6.59 \\
6.08 \\
7.65 \\
5.49\end{array}$ & $\begin{array}{r}170 \\
337 \\
169 \\
168 \\
111 \\
94 \\
170 \\
120 \\
198 \\
100\end{array}$ & $\begin{array}{l}\text { Alive; } P \text { and } K \text { functioning } \\
\text { Alive; } P \text { and } K \text { rejected } \\
\text { Alive; } P \text { and } K \text { functioning } \\
\text { Alive; } P \text { and } K \text { functioning } \\
\text { Alive; } P \text { and } K \text { functioning } \\
\text { Alive; } K \text { functioning, } P \text { thrombosed } \\
\text { Died after } K \text { and } P \text { rejection } \\
\text { Alive; } P \text { and } K \text { functioning } \\
\text { Alive; } P \text { and } K \text { functioning } \\
\text { Alive; } P \text { and } K \text { functioning }\end{array}$ \\
\hline
\end{tabular}

- Patient had been receiving insulin since August 1984 with residual $C$ peptide excretion.

Conversion: SI to traditional units-Creatinine: $1 \mu \mathrm{mol} / 1 \approx 0.01 \mathrm{mg} / 100 \mathrm{ml}$.

TABLE II-Circadian mean (SEM) blood glucose, serum free insulin, blood $\beta$-hydroxybutyrate and lactate, and plasma glucagon concentrations in 10 diabetics with pancreas and renal transplants and six normal subjects. [Ranges given in square brackets]

\begin{tabular}{|c|c|c|c|c|c|c|}
\hline Case No & $\begin{array}{l}\text { Glucose } \\
(\mathrm{mmol} / \mathrm{l})\end{array}$ & $M$ Value & $\begin{array}{l}\text { Free insulin } \\
(\mathrm{mU} / \mathrm{l})\end{array}$ & $\begin{array}{l}\beta \text {-Hydroxybutyrate } \\
(\mu \mathrm{mol} / \mathrm{l})\end{array}$ & $\begin{array}{l}\text { Lactate } \\
(\mathrm{mmol} / \mathrm{l})\end{array}$ & $\begin{array}{l}\text { Glucagon } \\
(\mathrm{ng} / \mathrm{l})\end{array}$ \\
\hline 1 & $5 \cdot 9(0 \cdot 15)[4 \cdot 7-7 \cdot 3]$ & $2 \cdot 60$ & \multirow{10}{*}{$\begin{array}{l}40 \cdot 4(4 \cdot 18) \\
{[22-85]} \\
46 \cdot 4(4 \cdot 77) \\
{[12-88]} \\
26 \cdot 6(1 \cdot 90) \\
{[13-44]} \\
18 \cdot 4(3 \cdot 80) \\
{[1-73]} \\
28 \cdot 3(3 \cdot 14) \\
{[12-68]} \\
29 \cdot 4(2 \cdot 61) \\
{[16-56]} \\
28 \cdot 9(1 \cdot 60) \\
{[16-46]} \\
45 \cdot 6(4 \cdot 90) \\
{[19-100]} \\
23 \cdot 1(3 \cdot 30) \\
{[7-49]} \\
23 \cdot 0(3 \cdot 30) \\
{[7-50]}\end{array}$} & \multirow{10}{*}{$\begin{array}{l}113 \cdot 9(21 \cdot 90) \\
{[20-348]} \\
46 \cdot 2(7 \cdot 32) \\
{[10-130]} \\
25 \cdot 5(6 \cdot 47) \\
{[5-100]} \\
450 \cdot 0(67 \cdot 80) \\
{[55-960]} \\
90 \cdot 0(22 \cdot 30) \\
{[10-360]} \\
262 \cdot 6(57 \cdot 50) \\
{[10-1140]} \\
441 \cdot 5(36 \cdot 70) \\
{[177-671]} \\
615 \cdot 9(22 \cdot 30) \\
{[400-750]} \\
645 \cdot 1(9 \cdot 43) \\
{[577-690]} \\
628 \cdot 9(12 \cdot 70) \\
{[580-704]}\end{array}$} & \multirow{10}{*}{$\begin{array}{l}0.635(0.027) \\
{[0.397-0.847]} \\
0.703(0.042) \\
{[0.388-1.198]} \\
0.987(0.036) \\
{[0.706-1.208]} \\
0.821(0.041) \\
{[0.506-1.139]} \\
0.79(0.03) \\
{[0.56-1.05]} \\
0.75(0.16) \\
{[0.43-1.60]} \\
0.39(0.01) \\
{[0.34-0.49]} \\
1.01(0.09) \\
{[0.59-2.17]} \\
0.60(0.03) \\
{[0.40-0.81]} \\
0.73(0.04) \\
{[0.46-1.01]}\end{array}$} & \multirow{10}{*}{$\begin{array}{l}124 \cdot 75(3 \cdot 41) \\
{[115-165]} \\
126 \cdot 5(6 \cdot 37) \\
{[45-185]} \\
91 \cdot 00(5 \cdot 23) \\
{[55-160]} \\
69 \cdot 72(5 \cdot 99) \\
{[45-110]} \\
147 \cdot 8(4 \cdot 60) \\
{[125-195]} \\
119 \cdot 7(4 \cdot 70) \\
{[85-160]} \\
153 \cdot 7(3 \cdot 90) \\
{[125-195]} \\
243 \cdot 7(7 \cdot 60) \\
{[195-300]} \\
143 \cdot 0(8 \cdot 50) \\
{[110-230]} \\
131 \cdot 5(4 \cdot 30) \\
{[85-180]}\end{array}$} \\
\hline 2 & $7 \cdot 1(0.34)[4 \cdot 5-9 \cdot 9]$ & 6.05 & & & & \\
\hline 3 & $6.9(0 \cdot 31)[4 \cdot 2-10 \cdot 4]$ & $6 \cdot 70$ & & & & \\
\hline 4 & $6.1(0.33)[4 \cdot 2-8 \cdot 9]$ & 6.05 & & & & \\
\hline 5 & $6.2(0.19)[4 \cdot 8 \cdot 8 \cdot 7]$ & 3.90 & & & & \\
\hline 6 & $5 \cdot 9(0 \cdot 16)[4 \cdot 8-7 \cdot 2]$ & $3 \cdot 40$ & & & & \\
\hline 7 & $6.4(0 \cdot 16)[5 \cdot 4-7 \cdot 9]$ & 0.20 & & & & \\
\hline 8 & $7 \cdot 8(0.41)[5 \cdot 9-13 \cdot 3]$ & $8 \cdot 70$ & & & & \\
\hline 9 & $7 \cdot 0(0.31)[5 \cdot 4-9 \cdot 7]$ & 4.00 & & & & \\
\hline 10 & $6.4(0.27)[4.9-9.7]$ & $4 \cdot 60$ & & & & \\
\hline $\begin{array}{l}\text { Mean in transplant } \\
\text { recipients }\end{array}$ & $6.5(0.21)^{*}$ & $4.62(0.75)$ & $31.0(3.00)$ & $331.9(80.20)$ & $0.741(0.06)^{* *}$ & $135 \cdot 1(14 \cdot 50)$ \\
\hline Mean control value & $5.2(0.17)$ & & $16.9(1.80)$ & $113.9(18.90)$ & $0.916(0.01)$ & \\
\hline
\end{tabular}

p $<0.01$ compared with normal.

$0.05<\mathrm{p}<0.1$ compared with normal.

Conversion: SI to traditional units-Glucose: $1 \mathrm{mmol} / 1 \approx 18 \mathrm{mg} / 100 \mathrm{ml}$. $\beta$-Hydroxybutyrate: $1 \mu \mathrm{mol} / 1 \approx 0 \cdot 1 \mu \mathrm{g} / \mathrm{ml}$. Lactate: $1 \mathrm{mmol} / 1 \approx$ $9 \mathrm{mg} / 100 \mathrm{ml}$.

the same conditions as described for the patients, except that glucagon profiles were not determined.

Assays-Blood glucose was measured enzymatically by autoanalyser. Blood lactate and $\beta$-hydroxybutyrate values were measured as follows: after each sampling $1 \mathrm{ml}$ blood was pipetted immediately into an ice cold tube containing $1 \mathrm{ml} 10 \%(1 \mathrm{~N})$ perchloric acid, shaken vigorously, and centrifuged at $4^{\circ} \mathrm{C}$ within 60 minutes; the supernatant was separated and stored at $-20^{\circ} \mathrm{C}$ until spectrophotometric assay. ${ }^{12}$ For the measurement of plasma immunoreactive glucagon blood was collected immediately after sampling into ice cold plastic tubes containing sodium edetic acid (EDTA) and aprotinin, centrifuged at $4^{\circ} \mathrm{C}$, and the plasma stored at $-20^{\circ} \mathrm{C}$ for subsequent analysis; the antibody $R 78$, $\mathrm{C}$ terminus directed (supplied by Serono Biodata, Rome), was used at a final concentration of $1 / 50000$. Incubation was for 48 hours at $4^{\circ} \mathrm{C}$ and free immunoreactive glucagon was separated from bound immunoreactive glucagon by centrifugation at $2000 \mathrm{~g}$ for 20 minutes. Serum free insulin and $C$ peptide concentrations were measured by radioimmunoassay (Novo Research Institute RIA kit, Bagsvaerd, Denmark $)^{13} 14$ after precipitation of antibody bound insulin by polyethylene glycol. ${ }^{15} 16$

Statistical analysis-All data are expressed as means and standard error of mean (SEM). Data from the six normal subjects (shaded areas in the figure) are expressed as the mean and one standard deviation. $M$ Values were calculated according to Schlichtkrull et al. ${ }^{17}$ Statistical comparisons were by the Wilcoxon rank sum test.

\section{Results}

Table II and the figure show the mean 24 hour values, and their variations, for blood glucose, serum free insulin, plasma glucagon, blood lactate, and $\beta$-hydroxybutyrate. Mean blood glucose concentra- tion in the transplant group was within the normal range at 0700 after an overnight fast $(5.2$ (SEM 0.18$) v 5.3(0.23) \mathrm{mmol} / \mathrm{l}$ in the controls $(94.3(3.30) v 95.3(4.25) \mathrm{mg} / 100 \mathrm{ml}) ; \mathrm{NS})$ and was slightly higher than the values observed in the normal subjects for the rest of the day $(6.5(0.19) v 5.2(0.17) \mathrm{mmol} / \mathrm{l}(118.0(3.5) v 93.8(3.1) \mathrm{mg} / 100$ $\mathrm{ml}) ; \mathrm{p}<0.01)$. The circadian glucose oscillations observed in the transplant recipients were similar to those observed in the normal subjects and, on average, did not exceed $7.9 \mathrm{mmol} / 1(142 \mathrm{mg} / 100 \mathrm{ml})$, although on two occasions in two patients values above $10.0 \mathrm{mmol} / 1(180 \mathrm{mg} /$ $100 \mathrm{ml})$ were observed $(10.4 \mathrm{mmol} / 1(187 \mathrm{mg} / 100 \mathrm{ml})$ at 2400 in case $3 ; 13.3 \mathrm{mmol} / 1(239 \mathrm{mg} / 100 \mathrm{ml})$ at 2100 in case 8$)$. Lower mean glycaemic values were observed in the two patients (cases 1 and 4 ) treated with cyclosporin only $(5.9$ (SEM 0.15$)$ and $6.1(0.33) \mathrm{mmol} / \mathrm{l}$ $(106.8(2.7)$ and $109.7(5.9) \mathrm{mg} / 100 \mathrm{ml})$, respectively) compared with those receiving steroids as part of the immunosuppressive treatment $(6.7(0.21) \mathrm{mmol} / 1 ; 121.0(3.8) \mathrm{mg} / 100 \mathrm{ml})$.

The $M$ value of the transplant recipients was 4.62 (SEM 0.75).

The mean 24 hour serum free insulin concentrations in the transplant group were higher than those observed in the controls $(31.0$ $(\mathrm{SEM} 3.0)$ v $16.9(1.8) \mathrm{mU} / \mathrm{l} ; \mathrm{p}<0.01)$, with persistent hyperinsulinaemia between meals and at night. Insulin secretion peaks in response to meals were delayed in the transplant group compared with controls (0900 $v 0800$ after breakfast, $1500 v 1400$ after lunch, and 2000 $v 1900$ after dinner, respectively).

The mean blood $\beta$-hydroxybutyrate concentrations over the 24 hours were on average higher in the transplant group than in the controls (331.9 (SEM 80.2) $v 113.9$ (18.9) $\mu \mathrm{mol} / 1$ (34.6 (8.3) $v 11.9$ $(2 \cdot 0) \mu \mathrm{g} / \mathrm{ml})$, respectively), although the wide variability within the transplant group did not produce any statistical significance. The pattern of the 24 hour variations was the same in the two groups, however, and was characterised by a progressive increase at night and between meals, followed by a decrease after meals.

The mean 24 hour blood lactate concentrations were lower in the 
transplant recipients than in the controls (0.74 (SEM 0.06) $v 0.92$ $(0.01) \mathrm{mmol} / 1(6.7(0.54)$ v $8.3(0.09) \mathrm{mg} / 100 \mathrm{ml})$, respectively; 0.05 $<\mathrm{p}<0.1)$. In both groups a transient and small increase in lactate occurred after meals, followed by a rapid return to preprandial values.

The mean plasma glusagon concentration in the transplant recipients was $135 \cdot 1$ (SEM 14.5) ng/l. The mean profile was characterised by an increase in circulating glucagon in the late afternoon and evening, peaking at 1900 , with return to basal values at 2400 . Glucagon was not measured in the controls; however, using the same method in another group of 12 healthy subjects we obtained a mean fasting concentration of $137.0(13.61) \mathrm{ng} / \mathrm{l}$.

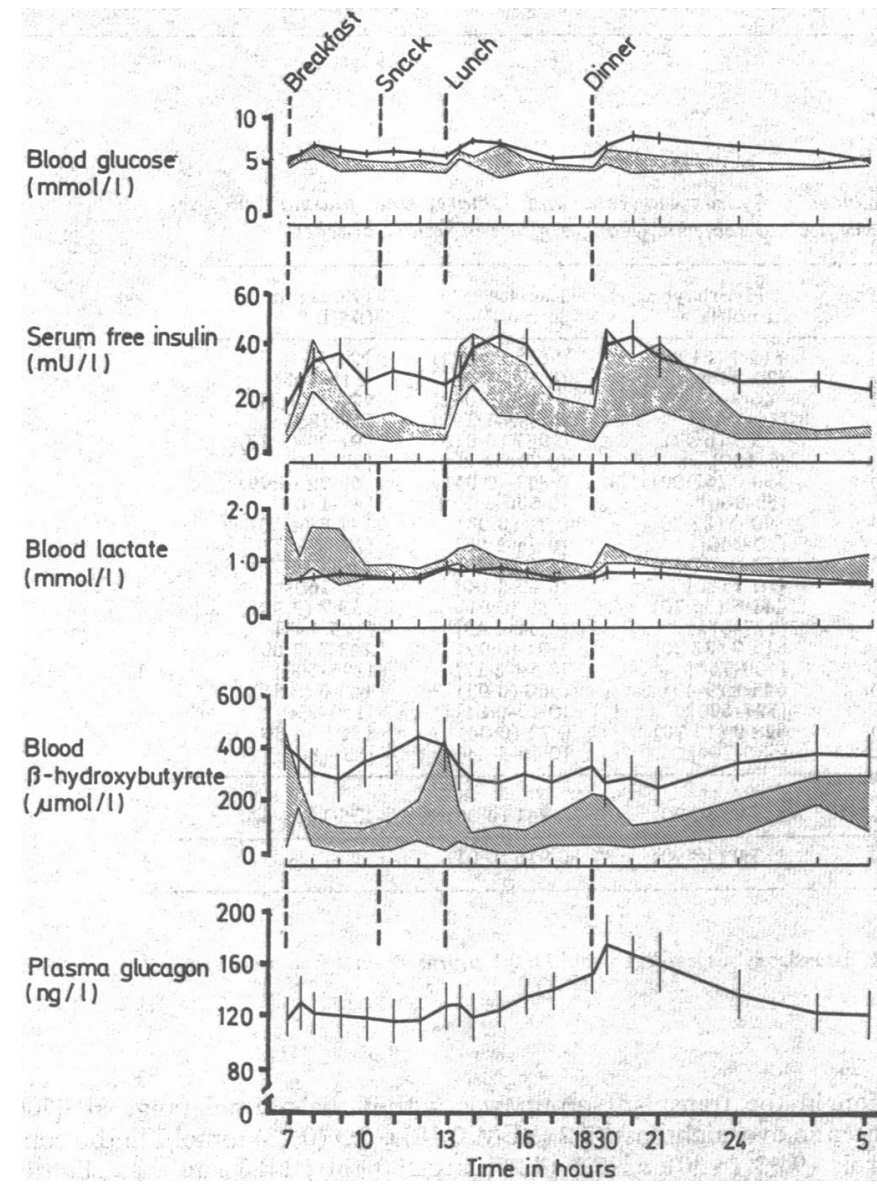

Mean circadian profile of blood glucose, serum free insulin, blood lactate and $\beta$-hydroxybutyrate, and plasma glucagon concentrations in 10 patients with pancreas and renal transplants. Shaded areas represent mean and one standard deviation for observations in six normal subjects.

Conversion: SI to traditional units-Glucose: $1 \mathrm{mmol} / 1 \approx 18 \mathrm{mg} / 100 \mathrm{ml}$. Lactate: $1 \mathrm{mmol} / 1 \approx 9 \mathrm{mg} / 100 \mathrm{ml}$. $\beta$-Hydroxybutyrate: $1 \mu \mathrm{mol} / 1 \approx 0.1 \mu \mathrm{g} / \mathrm{ml}$.

\section{Discussion}

After the early disappointing results ${ }^{18}$ the development of simpler and more satisfactory techniques for controlling the exocrine secretion ${ }^{11}$ led to renewed interest in pancreas transplantation and to a steadily increasing number of these operations performed world wide, ${ }^{19}$ several of the grafts functioning for long periods. ${ }^{20}$ Nevertheless, the side effects of immunosuppression and our inability to detect early rejection remain serious drawbacks and are a contraindication to transplanting the pancreas alone. In uraemic diabetic patients requiring a renal graft, however, the association of a pancreas graft does not seem to represent an undue additional risk. Moreover, the renal graft may protect the pancreas graft against rejection..$^{22-24}$ Thus most investigators prefer to transplant both organs, either simultaneously or at separate operations.

In our experience with simultaneous transplantation the functional survival rate of pancreas grafts is currently about $50 \%$ at six months, $34 \%$ at one year, and $25 \%$ at two years, and these figures may be improved to almost $40 \%$ survival at two years with immunosuppressive protocols including cyclosporin. ${ }^{21} 25$ Our technique of suppressing the exocrine secretion by obstructing the pancreatic duct with neoprene is simple and safe, as it reduces the operation to a vascular anastomosis with the recipient's iliac vessels and avoids the necessity for intestinal surgery. The fibrosis induced by this kind of polymer injection preserves the integrity of the islet tissue ${ }^{26}$ and does not seriously impair endocrine function in the long term. ${ }^{27}$ Nevertheless, in our case 4 fibrosis was probably the cause of a slow and progressive decline of pancreatic function which led to resumption of insulin 41 months after transplantation (table I). Some investigators have used a more refined technique for diverting the pancreatic juice, anastomosing the pancreatic duct to a jejunal loop aiming at better preservation of islet tissue compared with techniques occluding the duct. ${ }^{28}{ }^{29}$ More recently, a technique of paratopic grafting has also been described, allowing drainage of hormone secretions into the portal system. ${ }^{30}$

In our patients the endocrine function of the pancreas graft differed from that of the normal pancreas for several intrinsic and environmental reasons-reduced islet mass (segmental graft, possible partial rejection, surrounding fibrosis, ischaemic injuries); hormone delivery into peripheral circulation, bypassing the portal system; denervation; relatively impaired renal function; immunosuppressive treatment. Our study shows that despite these complications the pancreas transplant can correct the metabolic abnormalities of diabetes. Indeed, our patients not only became insulin independent but achieved near normal blood glucose concentrations throughout the 24 hours: in eight of the 10 patients the concomitant administration of steroids as part of the immunosuppressive treatment resulted in only a slight increase in glycaemia.

The insulin profiles were characterised by hyperinsulinaemia between meals and at night and by delayed postprandial peaks. The hyperinsulinaemia may have occurred because of the peripheral rather than portal delivery of insulin; circulating insulin concentrations higher than normal are common in insulin dependent diabetics receiving insulin by a peripheral route (subcutaneous, intramuscular, or intravenous) since higher peripheral concentrations are needed in order to provide the liver with amounts adequate for glucose homoeostasis. In addition, steroid treatment may have contributed to hyperinsulinaemia. The delayed postprandial insulin peaks probably reflected the denervation of the pancreas graft. In previous studies we observed a delayed insulin response to oral glucose, although not to arginine and tolbutamide. ${ }^{910}$ Whether additional mechanisms were responsible for the delayed insulin response to meals remains to be determined.

Blood lactate concentrations in the transplant recipients were within the normal range.

The $\beta$-hydroxybutyrate concentrations observed during the 24 hours in the transplant recipients were higher than in the controls; nevertheless, the circadian profiles were comparable, showing an inverse relation with the pattern of insulin secretion. It is difficult to explain this mild hyperketonaemia in the absence of hyperglycaemia: it may be that the insulin concentration at the hepatic level was sufficient to control glucose but not ketone body production. Whether steroid administration and other contrainsulin hormones or factors may have played a part remains to be established. Of these, certainly glucagon may have been at least partially responsible since its concentrations in the transplant recipients, although within the normal range, may be considered to have been inappropriately raised in relation to the blood glucose values. The 24 hour plasma glucagon profiles showed almost constant values during the night, morning, and early afternoon, with an increase in the late afternoon and evening.

In summary, our findings show that pancreas transplantation not only leads to insulin independence and the disappearance of the clinical symptoms and signs of insulin deficiency but is also associated with return to normal or near normal concentrations of blood glucose and intermediary metabolites. The peculiar 
physiology of the pancreas graft, which is heterotopic and denervated, together with the immunosuppressive treatment and relatively impaired renal function might be responsible for minor differences in hormonal and metabolic patterns.

Results comparable to ours have been described in non uraemic type I diabetic patients treated with artificial endocrine pancreas; continuous subcutaneous, intravenous, or intraperitoneal insulin infusions; and intensified conventional insulin treatments. ${ }^{31-35}$

Pancreas transplantation seems an ethical proposition in type I diabetic patients undergoing kidney transplantation for chronic renal failure and in whom immunosuppression is to be used. In these cases pancreas transplantation, when successful, leads to the restoration of normal metabolic homoeostasis without hormone replacement.

We thank Dr M Seoud El Yafi for help in the care of the patients and Professor Piero P Foa for reviewing the manuscript. This work was supported in part by the Consiglio Nazionale delle Ricerche, Italy (CNR Progetto Finalizzato Malattie Croniche e Degenerative, Sottoprogetto 4, Obiettivo 46), and by the Juvenile Diabetes Foundation, USA (file No 184066).

\section{References}

1 Sutherland DER. Pancreas and islet transplantation I. Experimental studies.

Diabetologia $1981 ; 20: 161-85$.
Sutherland DER. Pancreas and islet transplantation II. Clinical trials. Diabetologia

3 Lacy PE, Davie JM, Finke EH. Transplantation of insulin producing tissue. Am 7 Med 1981;70:589-94.

4 Ostman J, Arner P, Groth CG, Gunnarson R, Heding LG, Lundgren G. Plasma $C$-peptide and serum insulin antibodies in diabetic patients receiving pancreas

5 McMaster P, Gibby OM, Calne RY, et al. Human pancreatic transplantation: preliminary studies of carbohydrate control. Transplant Proc 1981;13:371-3. Sutherland DER, Najarian JS, Greensberg BZ, et al. Hormonal and metabolic effects of a pancreatic endocrine graft. Ann Intern Med 1981;95:537-41.

Traeger J, Dubernard JM, Bosi E, et al. Human segmental pancreatic transplantation for the treatment of insulin dependent diabetes. In: Keen $\mathrm{H}$, Legrain $M$ 1983:221-9.

8 Traeger J, Dubernard JM, Pozza G, et al. Influence of immunosuppressive therapy on the endocrine function of segmental pancreatic allografts. Transplan Proc 1983;15:1326-9.

9 Pozza G, Traeger J, Dubernard JM, et al. Endocrine responses of type-1 (insulindependent) diabetic patients following successful pancreas transplantation.

Traeger J, Dubernard JM, Pozza G, et al. Functional study of insulin secretion
Trabetion pattern following segmental neoprene-injected pancreatic allograft in insulin 11 Dubernard JM, Traeger J, Neyra P, Touraine JL, Tranchant D, Blanc-Brunat N. A new method of preparation of segmental pancreatic grafts for transplantation: trials in dogs and in man. Surgery 1978;84:633-9.
ergmeyer HU, ed. Methoden der enzymatischer analyse. Weinheim: Verlag 2 Bergmeyer HU

13 Heding LG. Determination of total serum insulin in insulin treated diabetic patients. Diabetologia $1972 ; 8: 260-6$

14 Heding LG. Radioimmunological determination of human C-peptide in serum Diabetologia 1975;11:541-8.

15 Nakagawa S, Nakayama H, Sasaki $T$, et al. A simple method for the determination of serum free insulin levels in insulin treated patients. Diabetes 1973;22

16 Heding LG, Karperska-Czyzykowa T. C-peptide and proinsulin after oral glucose.

17 Schlichtkrull J, Munck D, Jersild $M$. The $M$-value, an index of blood sugar control in diabetics. Acta Med Scand 1965;177:95-102.

18 Lillehei RC, Simmons RL, Najarian JS, et al. Pancreaticoduodenal allotransplantation. Experimental and clinical experience. Ann Surg 1970;172:405-36.

19 Sutherland DER, Kendall D. Clinical pancreas and islet transplant registry report. Transplant Proc 1985;17:307-11.

20 Sutherland DER, Goetz FC, Najarian JS. Recent experience with 89 pancreas transplants at a single institution. Diabetologia 1984;27:149-53.

21 Traeger J, Bosi E, Dubernard JM, et al. Thirty months' experience with cyclosporin in human pancreatic transplantation. Diabetologia 1984;27:154-6. Patterns of renal and pancreatic rejection in double-grafted patients. Transplant Proc 1981;13:305-7.

23 Severyn W, Olson L, Miller J, et al. Studies on the survival of simultaneous canine renal and segmental pancreatic allografts. Transplantation 1982;33 606-12.

24 Traeger J, Dubernard JM, Piatti PM, et al. Clinical aspects of pancreatic rejection in pancreatic and pancreaticorenal allotransplants. Transplant Proc 1984;16:

25 Traeger J, Dubernard JM, Piatti PM, et al. Cyclosporin in double simultaneous pancreas plus kidney transplantation. Transplant Proc 1985;17:336-9. after intraductal neoprene injection in dogs and diabetic patients treated by pancreatic transplantation. Diabetologia 1983;24:97-107.

27 Di Carlo V, Chiesa R, Pontiroli AE, et al. Intraductal injection of neoprene to suppress native pancreatic exocrine secretion in humans: clinical and metabolic evaluation. Transplant Proc 1984;16:736-8.

28 Calne RY, White DJG, Rolles K, Duffy TJ, Kass T. Renal and segmental pancreatic grafting with draining of exocrine secretion and initial continuous intravenous cyclosporin-A in a patient with
failure. $B r$ Med $₹ 1982 ; 285: 677-80$.

29 Groth CG Collste H, Lundgren G, et al. Successful outcome of segmental human pancreatic transplantation with enteric exocrine diversion after modifications in technique, Lancet 1982 ;ii:522-4.

30 Calne RY. Paratopic segmental pancreas grafting: a technique with portal venous drainage. Lancet 1984;i:595-7.

31 Saibene V, Melandri M, Brembilla L, Spotti D, Pozza G. Comparison between multi-injection and continuous subcutaneous insulin therapy in insulindependent diabetic patients. Acta Diabetol Lat 1981;18:45-50.

32 Rizza RA, Gerich JE, Haymond MW, et al. Control of blood sugar in insulin dependent diabetes: comparison of an artificial endocrine pancreas, continuous subcutaneous insulin infusion

33 Calabrese G, Bueti A, Santeusanio F, et al. Continuous subcutaneous insulin infusion in insulin dependent diabetic parients: a comparison with conventiona optimized treatment in a long term study. Diabetes Care 1982;5:457-65.

34 Schiffrin A, Belmonte MM. Comparison between continuous insulin and multiple injections of insulin. A one year prospective study. Diabetes 1982;31:255-64. 35 Pozza G, Spotti D, Micossi $P$, et al. Long-term continuous intraperitoneal insulin treatment in brittle diabetes. Br Med $\mathcal{F} 1983 ; 286: 255-6$.

(Accepted 11 April 1985)

\section{Oral cholestyramine increases elimination of warfarin after overdose}

Warfarin overdose often requires a long period in hospital because of the prolonged duration of action of the drug. We describe how oral cholestyramine may speed clearance and reduce the period of hospital stay.

\section{Case history}

A 25 year old man was admitted one hour after taking an overdose of an unknown amount of warfarin, 10 dextropropoxyphene tablets, and alcohol. He had been run over by a fire engine one year previously and received warfarin for two months for a subsequent pulmonary embolus. Clinical findings were normal but he refused gastric lavage or emesis. His paracetamol concentration was $53 \mathrm{mg} / \mathrm{l}$ after four hours and his serum alcohol concentration $37.5 \mathrm{mmol} / \mathrm{l}(173 \mathrm{mg} / 100 \mathrm{ml})$. Liver function values were normal throughout, although his British comparative ratio (international normalised ratio) (BCR (INR)) on admission was 1.3 .

He was given vitamin $\mathrm{K} 10 \mathrm{mg}$ intramuscularly and then oral vitamin $\mathrm{K}$ $10 \mathrm{mg}$ daily (figure). Two days later his BCR had risen to 9.2 and he was given a further $10 \mathrm{mg}$ of vitamin $\mathrm{K}$ intramuscularly. Oral vitamin $\mathrm{K}(10 \mathrm{mg})$ continued to be administered, but after a further two days his BCR had risen to $8 \cdot 8$. Oral cholestyramine ( $4 \mathrm{~g}$ four times a day) was started and vitamin $\mathrm{K}$
( $10 \mathrm{mg}$ daily) continued intravenously. His BCR remained between 1.5 and 1.7 for the four days of his hospital stay and he did not develop bruising or bleeding at any time.

Plasma warfarin concentrations were measured by high performance liquid chromatography. ${ }^{1}$ The concentration fell $\log$ linearly from $13 \mathrm{mg} / 1$ six hours after the overdose with a half life of elimination of 53 hours. After cholestyramine the plasma warfarin concentration continued to decline log linearly but with a half life of 33 hours.

\section{Comment}

In a report of a patient taking $250 \mathrm{mg}$ warfarin Bjornsson and Blaschke initially administered vitamin $\mathrm{K}$ intravenously but then gave oral vitamin $\mathrm{K}$ with good response when the prothrombin time rose three days later. ${ }^{2}$ In our patient repeated oral doses of vitamin $K$ (10 mg daily) failed to prevent steep rises in the BCR. Park and coworkers showed that bioavailability of oral vitamin $K$ is low and very variable $(10-63 \%){ }^{3}$ We therefore concur with the recommendations of Bjornsson and Blaschke that vitamin $\mathrm{K}$ should be given parenterally, ${ }^{2}$ although we do not agree that it must be given three to five times daily. In our patient a single dose of $10 \mathrm{mg}$ vitamin $K$ parenterally was enough to bring the BCR down within 24 hours on two separate occasions, and this dose given intramuscularly (if the BCR is less than 2.0 ) or by slow intravenous injection on a twice daily basis should be sufficient in most circumstances. The exact dose and frequency should be governed by the BCR. 